\title{
Differences in Perception of Stress of Physiotherapists Employed in Various Departments
}

1 Mia Milojević

1 Ivan Brumini

${ }^{1}$ Ivana Crnković

1 University of Applied Health Sciences, Zagreb, Croatia

Article received: 11.11.2019.

Article accepted: 28.01.2020.

DOI: $10.24141 / 2 / 4 / 1 / 2$

Author for correspondence:

Mia Milojević

University of Applied Health Sciences Zagreb

Mlinarska 38, Zagreb, Croatia

E-mail: miamilojevic55@gmail.com

Keywords: perceived stress, physiotherapists, clinical environment

\section{Abstract}

Stress in the workplace represents a specific type of stress, stemming from the work environment. Stressful situations at work can trigger negative emotions that are linked with anxiety, tension, depression, fa- tigue and lack of working motivation. The aim of this research is to investigate differences in the perception of stress of physiotherapists employed in various departments. The research was conducted using an online questionnaire aimed at 123 physiotherapists in the Republic of Croatia. The results have showed that respondents perceived their workplace as moderately stressful. Considering the difference in the experience and perception of stress with regard to the department where physiotherapists work, the results have showed that there is a statistically significant difference in the level of perceived stress among the respondents with regard to the department in which they are employed. It was found that respondents employed in orthopaedics perceived stress to a lesser extent than those individuals employed in health centres and in the department of physical medicine and rehabilitation. The differences in the perception of stress among the respondents who are employed in other departments have shown no statistically significant difference. It was shown that the respondents of 20-25 years of age were found to exhibit statistically significantly lower levels of perceived stress compared to subjects of 2636 years of age. There is no noted statistically significant difference in the perception of stress among other age groups. It was determined that participants with a lower net monthly salary exhibit statistically significant greater lever of perceived stress in comparison to participants with a net monthly salary that is greater than the average. The results of the study have shown that there are no statistically significant differences in the level of perceived stress among respondents in terms of gender, length of service, level of education or marital status. 


\section{Introduction}

Stress is an almost common experience and unavoidable concept in the modern life and work of each individual. The concept of stress has been the subject of numerous scientific research, not only in the field of health care, but also in the social and human sciences, and even in the fields of economy, politics and business. Each area defines stress in its own way, so in the contemporary literature there are numerous definitions of stress. In the literature reviews numerous studies examining the intensity of stress in healthcare professionals are found, but there is little research available on such phenomenon among the physiotherapists. In accordance to the author Ajduković, work or occupational stress indicates a discrepancy between the demands of the workplace and the environment with respect to our capabilities, desires and expectations to meet these requirements. Among the more stressful professions are those focused on working with people. The author states that the assisting professions are, first and foremost, health professionals most stressed by the susceptible group precisely because they are in direct communication with people who need someone else's help, and this communication, among other things, involves engaging in the emotional states of others. Meeting and experiencing human pain, suffering and trauma is a major burden on the mental lives of healthcare professionals (1). Ajduković divides the sources of occupational stress and the burnout syndrome into two groups: external and internal. External sources can be further categorized as those related to the working conditions, those stemmed from the organization of work, conditions arising from relationships with other people within the organization, and the kind of help that is offered. Under stressors that depend on the individual (individual's internal sources), the same author includes persons who have unrealistic job expectations and fail to adjust to reality (1). Due to there being no precise definition of the clinical environment, we have modified the understanding of the said term in accordance with Brajša (1994). As a clinical environment, we have included the building, equipment, budget, monthly salary, organization and labour distribution, documentation and mutual relationships and stances of employees, unwritten rules, mutual behaviours and mood in the work place (2).
There is numerous research that investigates the intensity of stress in medical workers, but there is fewer research about the said phenomenon in physiotherapists specifically. Croatian databases also lack research on the presence of this syndrome in physiotherapists. Authors Nathiya et al. (2017) have conducted an observational research about professional stress in physiotherapists. The aim of the research was to find stress factors in the workplace in 65 physiotherapists. The participants were distributed in two groups according to their employment in a public or private hospital. The author's conclusion was that physiotherapists working in public hospitals were under less stress when in comparison to those working in private hospitals due to factors related to communication and interpersonal relationships, as well as physical labour that is required of physiotherapists while performing physiotherapeutic procedures (3). Aim of the research (Mandy, Rouse, 1997) conducted with 31 younger participants was to investigate the level of burnout at the work place. The results have shown a moderate level of burnout. Factors that are most strongly connected with burnout at the workplace have included the quality/quantity of work, responsibility/authority, job satisfaction, work role and labour organization. Authors have concluded that recognizing burnout at the start of one's career can limit negative impacts of the said syndrome (4). A research conducted in Saudi Arabia investigated the level of burn-out amongst physiotherapists and the correlation between work and organisational factors. Participants have shown a moderate level or burnout that is reflected with median results obtained using three Maslach Burnout Inventory subscales. Majority of the participants demonstrated moderate to high levels of burnout. The said results are in accordance with our research (5).

\section{Aim}

The main aim of this research is to examine differences in the perception of stress of physiotherapists employed in different departments. The goal of the research is also to investigate the correlation between intensity of stress with respect to the socio-demographic characteristics of the respondents. Considering the set goals, the following problems were formulated: 
First problem: To determine if the experience of stress intensity differ with respect to the different departments in which physiotherapists work.

Second problem: To examine differences in perceived stress among physiotherapists of different socio-demographic characteristics (gender, age, total length of service, level of education, marital status, monthly income).

\section{Methods}

\section{Participants}

The research was conducted through an online questionnaire among 123 physiotherapists in the Republic of Croatia. Majority of the research participants were female, 105 (85.5\%), and there were 18 male participants (14.5\%). According to participants' age, they were distributed in age groups from 20 to 25 , 26 to 36, 37 to 57 and older than 57 years of age. $50.8 \%$ of participants were in the 26 to 36 age group ( $M=18.37)$. Total length of service was distributed into groups from 1 to 4 years of work, 5 to 10,10 to 20 and 20 and more. Majority of participants, $37.9 \%$, had length of service 1 to 4 years long. With regard to their professional qualifications, 73 respondents (58.9\%) have completed higher education (bachelor degree).

Majority of participants, $75.8 \%$, stated that they had a partner. Considering monthly salaries of almost half of the participants, $63.7 \%$ stated that they had less than a median net salary in the Republic of Croatia which was 6.438 HRK at the time when the study was conducted. In accordance with the data provided by the Croatian Bureau of Statistics, the median net salary of physiotherapists in the Republic of Croatia is 5.037 HRK. Data obtained in this research supports the stated figure.

According to the type of department where they are employed, participants were distributed in 7 groups: private practice, health centre/infirmary, home physical therapy, physical medicine and rehabilitation, internal medicine (cardiology/neurology), orthopedics. The last category consists of unemployed physiotherapists and students (Table 1 ).

\begin{tabular}{ccc|}
$\begin{array}{c}\text { Table 1. Distribution of respondents by type of } \\
\text { ward }\end{array}$ & \\
\hline Ward type & N & $\%$ \\
\hline Private practice & 14 & 11.38 \\
\hline Health centre/Infirmary & 16 & 13.0 \\
\hline Home physical therapy & 13 & 10.56 \\
\hline Physical medicine and rehabilitation & 26 & 21.13 \\
\hline Internal medicine (cardiology/neurology) & 23 & 18.68 \\
\hline Orthopedics & 20 & 16.26 \\
\hline The unemployed and students & 11 & 8.94 \\
\hline
\end{tabular}

\section{Instrument}

The first part of the questionnaire is the Socio-demographic Questionnaire, which was created for the purpose of this paper. We used it to collect general data pertaining to the socio-demographic characteristics of respondents: their age, gender, length of service, qualifications, type of department, marital status, and monthly income.

For the second part of the questionnaire, the Perceived Stress Scale (PSS) (Cohen et al. 1983) was selected, which measures the degree to which participants perceive their life as unpredictable, their inability to control it, when they are experiencing excessive load, which represents the three basic components of experiencing stress (6). The original English version of the Perceived Stress Scale was translated by two independent translators and by comparing the two translations, the final Croatian version of the questionnaire was constructed.

The scale (PSS) consists of 10 items, and the participants were asked how they felt and what they thought during the course of the past month. Responses were scored using a 0 to 4 rating scale, with 0 indicating Never, 1 Rare, 2 Sometimes, 3 Frequent, and 4 Permanent.

According to the author instruction of the scale (PSS), items 4, 5, 7 and 8 needed to be recoded because they were positively formulated and they were scored in the opposite direction (6). Individual scores on the Perceived Stress Scale (PSS) can range from 0 to 40 points. The total score is formed by summing up the participants' responses across all the items where a higher score indicates greater perceived stress. Scores ranging from 0 to 13 are considered as low stress levels. Next, points ranging from 14-26 
are considered to reflect moderate levels of stress, and the results that range from $27-40$ points are considered as high levels of stress (6).

When choosing a measuring instrument, we had in mind maintaining enough time required to complete the questionnaire so that respondents did not lose motivation to complete it and to hold their attention until the completion of the questionnaire. In addition, that the same had been previously described in the literature, validated, and that it had met all other metric characteristics.

There is a shorter and longer version of this questionnaire. Methodological validity, along with valid metric characteristics is the reason for including the short version of the Perceived Stress Scale into this research (7).

\section{Procedure}

The research was conducted during April 2019 through an online questionnaire among physiotherapists on the territory of the Republic of Croatia. The criteria for choosing participants was that they were licenced physiotherapists that were at the time of conducting this research employed in one of the wards. For the choice of the participant sample, we have chosen the social network web page "Facebook Croatian Physiotherapists" that satisfies the said criteria.

For conducting the research using an online questionnaire, an approval from the Croatian Physiotherapists' administrator was granted. The questionnaire was anonymous. All respondents voluntarily agreed to participate in the survey. The first part of the questionnaire contains a notice for the research participant outlining the topic of the paper, and briefly stating the purpose and aim of this research. At the beginning of each questionnaire there was an instruction on how to complete the questionnaire. Following the notification for the study participants, the participants completed the Socio-demographic Questionnaire, followed by the Perceived Stress Scale (6). The time required to complete the entire questionnaire ranged between 5 and 10 minutes.

\section{Statistics}

Statistical data processing was performed using the statistical program IBM SPSS Statistics 23.0. The analysis of the difference in the overall perception of stress among respondents by their department of employment, age, number of years (length) of service and qualifications was determined using oneway variance analysis (one-way ANOVA test), and as post-hoc test the Tukey's test was used.

The analysis of the difference in the overall perception of stress among the respondents irrespective of the department where they are employed, and based on gender $(M / F)$, marital status (single/with a partner) and monthly earnings (lower/higher than the net average monthly salary) has been determined using the t-test for independent samples.

\section{Results}

Table 2 shows 10 statements of the PSS questionnaire with the frequency of responses by means of individual claims/questions. For each individual statement, there is a number of participants that chose the statement, percentage of the total number, and mean value with an associated standard deviation (Mean \pm SD).

According to the Perceived Stress Scale author's instructions, the results are obtained by adding responses to 10 statements using one variable that signifies total perceived stress (N/40). In this research, the total score was 24 out of total 40 points which suggests that the participants view their work place are moderately stressful (6).

A one-way analysis of variance (one-way ANOVA) was performed and it was determined that there is a statistically significant difference in stress perception in regard to the work place type $(F=2.603, d f=6$, $p=0.021$ ). Results of post-hoc analysis (Tukey's test) are shown in Table 4.

The employees employed at a health centre as well as those employed at the physical medicine and rehabilitation wards show significantly higher intensity of perceived stress compared to the employees at the orthopedics (health centre vs. orthopedics $p=0.021$; physical vs. orthopedics $p=0.032$ ). The difference in the perception of stress among the respondents employed in other wards shows no statistically significant difference. 


\section{Table 2. Mean values of stress perception are determined for each individual statement}

\begin{tabular}{|c|c|c|c|c|c|c|c|}
\hline & Statement* & 0 & 1 & $\begin{array}{c}2 \\
\text { N (\%) }\end{array}$ & 3 & 4 & MEAN $\pm S D$ \\
\hline 1 & $\begin{array}{l}\text { How often were you feeling upset due to something } \\
\text { unexpected happening? }\end{array}$ & $\begin{array}{c}0 \\
(0)\end{array}$ & $\begin{array}{c}26 \\
(21.1)\end{array}$ & $\begin{array}{c}45 \\
(36.6)\end{array}$ & $\begin{array}{c}37 \\
(30.1)\end{array}$ & $\begin{array}{c}15 \\
(12.1)\end{array}$ & $2.33 \pm 0.95$ \\
\hline 2 & $\begin{array}{l}\text { How often have you felt like you had no control over } \\
\text { important things in your life? }\end{array}$ & $\begin{array}{c}14 \\
(11.4)\end{array}$ & $\begin{array}{c}35 \\
(28.5)\end{array}$ & $\begin{array}{c}39 \\
(31.7)\end{array}$ & $\begin{array}{c}30 \\
(24.4)\end{array}$ & $\begin{array}{c}5 \\
(4.1)\end{array}$ & $1.81 \pm 1.06$ \\
\hline 3 & How often have you felt nervous and stressed? & $\begin{array}{c}5 \\
(4.1)\end{array}$ & $\begin{array}{c}17 \\
(13.8)\end{array}$ & $\begin{array}{c}32 \\
(26)\end{array}$ & $\begin{array}{c}50 \\
(40.7)\end{array}$ & $\begin{array}{c}19 \\
(15.4)\end{array}$ & $2.50 \pm 1.04$ \\
\hline 4 & $\begin{array}{l}\text { How often have you felt certain in your abilities to } \\
\text { cope with personal problems? }\end{array}$ & $\begin{array}{c}25 \\
(20.3)\end{array}$ & $\begin{array}{c}54 \\
(43.9)\end{array}$ & $\begin{array}{l}27 \\
(22)\end{array}$ & $\begin{array}{l}16 \\
(13)\end{array}$ & $\begin{array}{c}1 \\
(0.8)\end{array}$ & $1.30 \pm 0.97$ \\
\hline 5 & $\begin{array}{c}\text { How often have you felt like things were developing } \\
\text { the way you want them to? }\end{array}$ & $\begin{array}{c}8 \\
(6.5)\end{array}$ & $\begin{array}{c}51 \\
(41.5)\end{array}$ & $\begin{array}{c}41 \\
(33.3)\end{array}$ & $\begin{array}{c}18 \\
(14.6)\end{array}$ & $\begin{array}{c}5 \\
(4.1)\end{array}$ & $1.66 \pm 0.92$ \\
\hline 6 & $\begin{array}{l}\text { How often have you felt like you cannot cope with } \\
\text { your responsibilities? }\end{array}$ & $\begin{array}{c}14 \\
(11.4)\end{array}$ & $\begin{array}{l}32 \\
(26)\end{array}$ & $\begin{array}{c}41 \\
(33.3)\end{array}$ & $\begin{array}{l}27 \\
(22)\end{array}$ & $\begin{array}{c}9 \\
(7.3)\end{array}$ & $1.86 \pm 1.09$ \\
\hline 7 & $\begin{array}{c}\text { How often were you able to control uncomfortable } \\
\text { situations in your life? }\end{array}$ & $\begin{array}{c}12 \\
(9.8)\end{array}$ & $\begin{array}{c}43 \\
(35)\end{array}$ & $\begin{array}{c}46 \\
(37.4)\end{array}$ & $\begin{array}{l}16 \\
(13)\end{array}$ & $\begin{array}{c}6 \\
(4.9)\end{array}$ & $1.68 \pm 0.99$ \\
\hline 8 & $\begin{array}{l}\text { How often have you felt like you were in control of } \\
\text { your work situation? }\end{array}$ & $\begin{array}{c}21 \\
(17.1)\end{array}$ & $\begin{array}{c}62 \\
(50.4)\end{array}$ & $\begin{array}{c}25 \\
(20.3)\end{array}$ & $\begin{array}{l}10 \\
(8.1)\end{array}$ & $\begin{array}{c}5 \\
(4.1)\end{array}$ & $1.27 \pm 0.93$ \\
\hline 9 & $\begin{array}{l}\text { How often were you angry due to things out of your } \\
\text { control? }\end{array}$ & $\begin{array}{c}6 \\
(4.9)\end{array}$ & $\begin{array}{c}31 \\
(25.2)\end{array}$ & $\begin{array}{c}31 \\
(25.2)\end{array}$ & $\begin{array}{c}42 \\
(34.1)\end{array}$ & $\begin{array}{c}13 \\
(10.6)\end{array}$ & $2.20 \pm 1.09$ \\
\hline 10 & $\begin{array}{l}\text { How often have you felt like difficulties were } \\
\text { accumulating more than you could bear? }\end{array}$ & $\begin{array}{c}14 \\
(11.4)\end{array}$ & $\begin{array}{c}41 \\
(33.3)\end{array}$ & $\begin{array}{c}33 \\
(26.8)\end{array}$ & $\begin{array}{l}27 \\
(22)\end{array}$ & $\begin{array}{c}8 \\
(6.5)\end{array}$ & $1.79 \pm 1.11$ \\
\hline
\end{tabular}

\section{Table 3. Distribution of mean value of total stress perception determined in regard to the type of ward where the participants were employed}

$\begin{array}{cccccc} & \text { N } & \text { Mean } & \text { SD } & \text { Minimum } & \text { Maximum } \\ \text { Private practice } & 14 & 18.07 & 6.306 & 8 & 27 \\ \text { Health centre } & 16 & 21.56 & 7.465 & 7 & 36 \\ \text { Home physical therapy } & 13 & 17.31 & 5.808 & 9 & 27 \\ \text { Physical medicine and rehabilitation } & 26 & 20.54 & 5.523 & 10 & 31 \\ \text { Neurology } & 23 & 18.3 & 5.372 & 9 & 26 \\ \text { Orthopedics } & 20 & 14.8 & 6.084 & 3 & 29 \\ \text { The unemployed } & 11 & 16.82 & 6.853 & 8 & 28 \\ \text { TOTAL } & 123 & 18.37 & 6.344 & 3 & 36\end{array}$

Results of total stress perception analysis in regard to age, sex, years of service, level of education, marital status and monthly salary are shown in Table 5.

A statistically significant difference was determined in the level of perceived stress in regard to age $(p=0.048)$. Participants aged $20-25$ showed a sta- tistically significant lower level of perceived stress $(p=0.044)$ in comparison to participants aged 2636. It was determined that participants with a lower net monthly salary exhibit statistically significant greater lever of perceived stress $(p=0.011)$ in comparison to participants with a net monthly salary that is greater than the average. 


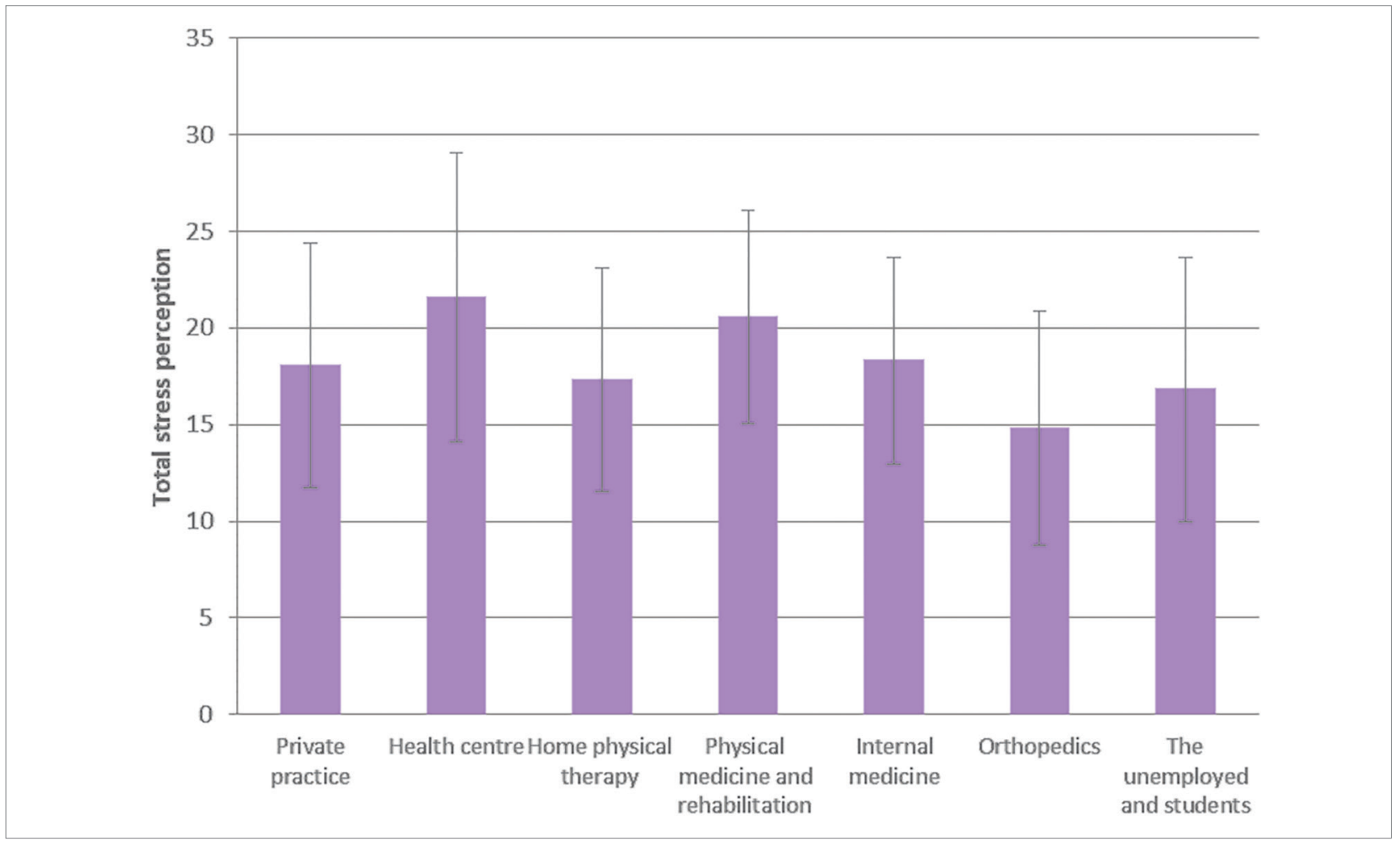

Figure 1. Graphical representation of the mean values of total stress perception with regard to the ward type where the participants were employed (columns signify arithmetic means, and vertical lines SD)

\section{Table 4. Comparison of perceived stress intensity between different wards ( $p$ values are shown)}

\begin{tabular}{|c|c|c|c|c|c|c|}
\hline & $\begin{array}{l}\text { Private } \\
\text { practice }\end{array}$ & $\begin{array}{l}\text { Health } \\
\text { centre }\end{array}$ & $\begin{array}{l}\text { Home } \\
\text { physical } \\
\text { therapy }\end{array}$ & $\begin{array}{l}\text { Physical } \\
\text { medicine and } \\
\text { rehabilitation }\end{array}$ & $\begin{array}{l}\text { Internal } \\
\text { medicine }\end{array}$ & Orthopedics \\
\hline \multicolumn{7}{|l|}{ Private practice } \\
\hline Health centre & 0.706 & & & & & \\
\hline Home physical therapy & 0.999 & 0.507 & & & & \\
\hline $\begin{array}{l}\text { Physical medicine and } \\
\text { rehabilitation }\end{array}$ & 0.885 & 0.998 & 0.709 & & & \\
\hline Internal medicine & 1.000 & 0.657 & 0.999 & 0.861 & & \\
\hline Orthopedics & 0.722 & 0.021 & 0.910 & 0.032 & 0.500 & \\
\hline $\begin{array}{c}\text { The unemployed and } \\
\text { students }\end{array}$ & 0.998 & 0.431 & 0.999 & 0.621 & 0.994 & 0.974 \\
\hline
\end{tabular}




\begin{tabular}{|c|c|c|c|c|}
\hline & $\mathbf{N}$ & Mean & SD & Statistics \\
\hline \multicolumn{5}{|l|}{ Age group } \\
\hline $20-25$ & 21 & 15.62 & 6.13 & \\
\hline $26-36$ & 63 & 19.78 & 6.63 & $F=2.71$ \\
\hline $37-57$ & 35 & 17.68 & 5.51 & $p=0.048^{*}$ \\
\hline Older than 57 & 4 & 16.50 & 5.20 & \\
\hline \multicolumn{5}{|l|}{ Sex } \\
\hline$M$ & 18 & 17.28 & 7.48 & $p=0.433$ \\
\hline $\mathrm{F}$ & 105 & 18.55 & 6.15 & \\
\hline \multicolumn{5}{|l|}{ Years of service } \\
\hline $1-4$ & 47 & 18.32 & 6.38 & \\
\hline $5-10$ & 24 & 20.17 & 7.57 & $F=0.98$ \\
\hline $10-20$ & 25 & 18.00 & 6.52 & $p=0.403$ \\
\hline More than 20 & 27 & 17.18 & 4.71 & \\
\hline \multicolumn{5}{|l|}{ Level of education } \\
\hline Secondary school & 7 & 23.00 & 2.38 & $F=2.26$ \\
\hline Higher education & 73 & 18.40 & 6.50 & $p=0.108$ \\
\hline University degree & 43 & 17.56 & 6.28 & \\
\hline \multicolumn{5}{|l|}{ Marital status } \\
\hline Single & 29 & 19.79 & 5.85 & $p=0.167$ \\
\hline With a partner & 94 & 17.92 & 6.45 & \\
\hline \multicolumn{5}{|l|}{ Monthly salary } \\
\hline $\begin{array}{l}\text { Lower than a median } \\
\text { net salary } \\
\text { in the Republic of } \\
\text { Croatia }\end{array}$ & 79 & 19.44 & 6.39 & $p=0.011^{\star *}$ \\
\hline $\begin{array}{c}\text { Higher than a } \\
\text { median net salary } \\
\text { in the Republic of } \\
\text { Croatia }\end{array}$ & 44 & 16.43 & 5.84 & \\
\hline
\end{tabular}

Other results show that there is no statistically significant difference between the level of perceived stress amongst participants in regard to sex $(p=0.403)$, level of education $(p=0.108)$ and marital status $(p=0.167)$.

\section{Discussion}

This research sought to determine whether physiotherapists employed in different departments differ in perceived stress. It also sought to determine if there is a difference in the overall experience of stress with respect to socio-demographic characteristics (gender, age, total length of service, level of education, marital status and monthly income).

By summing up the answers to the 10 claims it was found that physiotherapists in this study perceived the overall experience of stress as moderate. One can say that such a finding is consistent with other research in the world. For example, in a study by Campo, Weiser and Koenig, that was conducted in 2009 in the United States, the goal was to determine the impact of job demands on physiotherapists' stress and to compare it with other occupations. The sample consisted of 1500 randomly selected members of the American Association for Physical Therapy (APTA). Data were collected through the two validated questionnaires in the interval of one year. Physiotherapists' views on their work environment were positive. The level of stress and the job requirements were estimated as moderate (8).

In geographically and culturally diverse environments, research has shown approximately the same results. $A$ search of the literature shows that many studies have addressed the impact of stress on the work of healthcare professionals and their burnout in the workplace. Various authors have emphasized the importance of testing for the burnout syndrome in particular jobs. The conclusion for all of the research that was reported in this paper is that more studies need to be conducted to describe the characteristics of the work environment in this population. Also, the initiatives should be developed and studied in specific institutions that improve the psychosocial work environment for physiotherapists.

In Croatian databases, there is a lack of research aimed at the level of workplace stress in physiotherapists. Majority of research of this type has been conducted on doctors and nurses, while other professions are listed as "other medical staff" $(9,10)$. Research conducted using validated questionnaire are very few in the Republic of Croatia. There is a validated questionnaire aimed at medical workers that specifically inves- 
tigates stress at the workplace. Milošević (2010) is the author of the said questionnaire that is unsuitable for online research due to its extensiveness. Hence, we have decided to use the Perceived Stress Scale measuring instrument (PSS) (11). Research conducted by Knežević on how and how much stress in the workplace affects working capabilities of medical workers in the Republic of Croatia was conducted in 2010 with over 1856 medical workers that were employed in 5 different Zagreb hospitals on 19 different specialist wards and it shows that two thirds of medical workers identify their workplace as a source of stress. Sex and age are significantly negatively correlated with the indications of working capabilities of medical workers (12). In the research by Kraljević (2017) that was conducted in Croatia most common sources of stress in physiotherapists, level of working capabilities and the relationship between stress, working capabilities and socio-demographic characteristics were examined.

Results have demonstrated that physiotherapists evaluate potential sources of stress as slightly or moderately stressful. The author concludes that there is no statistically significant level of stress in physiotherapists in regard to their socio-demographic characteristics. On the stress intensity scale, most commonly recognized are those linked to work organization and financial restrictions. The said results are partially compliant with our research in which the level of stress at the workplace amongst physiotherapists was moderate. The author's scale of stress intensity corresponds with our conceptual definition of medical environment (13).

With regard to the difference in perceptions of stress between departments, this study has established that respondents employed in orthopaedics perceived stress to be significantly less significant than those employed in health centres and in the physical medicine and rehabilitation departments.

The health centre is an institution that implements primary health care measures in the local community. As a facility for a primary health protection level, the health centres addresses $80-85 \%$ of the community health issues. It is a filter of inputs to higher levels of the health system (secondary and tertiary health care levels), which are more inaccessible because they are fewer and therefore more expensive due to the use of expensive technologies. With this in mind it makes it possible to explain the results of this study, which show that physiotherapists working in the health centres and in the departments of physical medicine and rehabilitation are more stressed than those who work in the orthopaedics department (14).

The results that have been obtained among respondent physiotherapists employed in orthopaedics are somewhat unexpected. Although this is a ward that often keeps severely ill patients, patients of different ages and with a high proportion of the elderly individuals, and patients undergoing post-operative treatment after complex surgery, the research has shown that physiotherapists are under lower intensity of stress. On the other hand, in orthopaedics, physiotherapists have a lower dynamics of daily flow of patients, and consequently they have more time for individual access to the patient. A well-organized team approach and proportionally less individual workload is the result of the team collaboration. Physiotherapists do not make their own decisions but exchange experiences at team meetings. This may just be an explanation for the fact that the physiotherapists are less stressed.

In line with the socio-demographic characteristics, a statistically significant difference was found with respect to age. Respondents aged $20-25$ years showed significantly lower levels of perceived stress when compared to the subjects of 26-36 years of age. In the research students and the unemployed have also participated, and they are predominantly in the "good" age group of 20 to 25 years of age, and there is a possibility that the mentioned group would significantly change the result. Furthermore, the population of 67-year-old group of individuals contributed only to $3.3 \%$ in the survey, which also significantly changes the result.

It was determined that participants with a lower net monthly salary exhibit statistically significant greater lever of perceived stress in comparison to participants with a net monthly salary that is greater than the average.

In this study it was found that there was no statistically significant difference in the level of perceived stress among respondents with respect to gender, length of service, level of education or marital status.

In the sample, there is a disproportion between the number of bachelors (73) and graduates/individuals having a master's degree - a total of 43 individuals. The above represented data poses a limitation of this research given that the respondents do not fully represent the sample. 
One of the disadvantages of this research is related to the method of data collection. The use of self-rating scales is a potential drawback of this research. Since they are coupled with a tendency to give socially desirable and favourable answers, the honesty and objectivity of such responses is questioned. This deficiency could be solved by using other measuring instruments (such as peer evaluations) to provide more accurate answers.

The application of the online questionnaire has its advantages and disadvantages. This method of research application was used because it was a convenient way to reach more participants who needed to meet certain conditions. There was no possibility to control the conditions under which the questionnaires were filled in, which means that the identity of the participants, their age and gender cannot be verified. Also, there is no possibility of verifying the comprehension of the instructions, and we cannot monitor the participants' behaviour when completing the questionnaire and making sure that they participate in a serious manner. An important limitation of online research is the limited representativeness of a sample of Internet users for the entire population of physical therapists. Participants were not chosen by random selection but by voluntary participation. Therefore, the data obtained in this research should be interpreted carefully and cannot actually be generalized. In future research, it would certainly be interesting to confirm the results on a different specific sample (for example, the older population).

Another major drawback of this research is the use of the Perceived Stress Scale (PSS). This instrument is designed to test general non-specific stress and is one of the most commonly used instruments in psychological testing. It is possible that with the implementation of some other measuring instrument that specifically addresses the stress caused by workplace situations we could get different results. Therefore, the recommendation for future research is to apply or develop a more specific measurement scale.

Given the obtained results, research on a more representative sample of physiotherapists should be conducted, with respect to their age, gender, length of service, qualifications, etc. It would also be interesting to investigate possible regional differences in perceived stress among physiotherapists in the Republic of Croatia. Future research could focus on exploring guidelines for stress prevention or on other variables other than stress.
The advantage of this research is certainly that it is evidence-based and as such may serve as a starting point for some future scientific procedures.

\section{Conclusion}

Despite the relatively limited scientific evidence of physiotherapists' exposure to workplace stress, available research does indicate to a particular degree of self-perception of stress in the workplace. The results of the researches that were carried out in the world and the results obtained by the authors in the Republic of Croatia partly coincide with the results we have obtained in this paper.

With regard to the socio-demographic characteristics, a statistically significant difference was found with respect to age, with significantly lower levels of perceived stress that were exhibited by people from 20 to 25 years of age. It was determined that participants with a lower net monthly salary exhibit statistically significant greater lever of perceived stress in comparison to participants with a net monthly salary that is greater than the average.

The results of this study show that there is no statistically significant difference in the level of perceived stress among the respondents in terms of gender, length of service, level of education or marital status. With regard to the difference in the perception of stress between the departments, it was found that the respondents employed in orthopaedics perceived stress to a much lesser extent when compared to the respondents employed in health centres and physical medicine and rehabilitation departments. The difference in the perception of stress among the respondents employed in other departments shows no statistically significant difference.

When using the Perceived Stress Scale (PSS) at the level of total perceived stress, the results have shown that the subjects are exposed to moderate stress.

The findings obtained with this research can serve as a basis for future research at a higher scientific level, and as a basis for developing a strategy for reducing stress and thus preventing negative consequences in the workplace. 


\section{References}

1. Ajduković D. Izvori profesionalnog stresa i sagorijevanja pomagača. U: Ajduković D, Ajduković M, urednici. Pomoć i samopomoć u skrbi za mentalno zdravlje pomagača. Zagreb: Društvo za psihološku pomoć; 1996. Croatian.

2. Brajša P. Pedagoška komunikologija. Zagreb: Školska knjiga; 1994. Croatian.

3. Nathiya N, Sasikumar K, Jagannath M, Thangaraj M, Adalarasu K. An observational study on occupational stress among physiotherapists. Biomed Pharmacol J. 2017;10(2):889-94.

4. Mandy A, Rouse S. Burnout and work stress in junior physiotherapists. Br J Ther Rehabil. 1997;4:597-603.

5. Al-Imam DM, Al-Sobayel HI. The Prevalence and Severity of Burnout among Physiotherapists in an Arabian Setting and the Influence of Organizational Factors: An Observational Study. J Phys Ther Sci. 2014;26(8):1193-8.

6. Cohen S, Kamarck T, Mermelstein, R. A global measure of perceived stress. J Health Soc Behav. 1983;24(4):385-96.

7. Chiu YH, Lu FJ, Lin JH, Nien CL, Hsu YW, Liu HY. Psychometric properties of the Perceived Stress Scale (PSS): measurement invariance between athletes and nonathletes and construct validity. Peer J. 2016;4:e2790.
8. Campo MA, Weiser S, Koenig KL. Job strain in physical therapists. Phys Ther. 2009;89(9):946-56.

9. Buljubašić $A$. Sindrom sagorijevanja među zdravstvenim djelatnicima [diplomski rad]. Split: Sveučilište u Splitu; 2015. Croatian.

10. Strapajević D. Procjena utjecaja rada u integriranoj bolničkoj hitnoj službi na zdravlje i radnu sposobnost djelatnika. Sestrinski glasnik. 2015;20(3):231-9. Croatian.

11. Milošević M. Izrada mjernog instrumenta stresa na radnom mjestu bolničkih zdravstvenih djelatnika i procjena njegove uporabne vrijednosti [doktorska disertacija]. Zagreb: Sveučilište u Zagrebu; 2010. Croatian.

12. Knežević B. Stres na radu i radna sposobnost zdravstvenih djelatnika u bolnicama [doktorska disertacija]. Zagreb: Sveučilište u Zagrebu; 2010. Croatian.

13. Kraljević A. Stres i radna sposobnost kod fizioterapeuta [diplomski rad]. Zagreb: Zdravstveno veleučilište; 2017. Croatian.

14. Knežević B, Golubić R, Belošević $L$ ], Milošević M, Mustajbegović J. Očuvanje radne sposobnosti bolničkih zdravstvenih djelatnika. Acta Med Croatica. 2010;64(5):3914. Croatian. 


\section{RAZLIKE U PERCEPCIJI STRESA FIZIOTERAPEUTA ZAPOSLENIH NA RAZLIČITIM ODJELIMA}

\section{Sažetak}

Stres na radnom mjestu specifična je vrsta stresa, čiji je izvor u radnom okolišu. Stresne situacije na poslu mogu izazvati negativne emocije koje se povezuju s anksioznošću, napetošću i nedostatkom motivacije za rad. Cilj je ovog rada ispitati razlike u percepciji stresa fizioterapeuta zaposlenih na različitim odjelima. Istraživanje je provedeno putem online upitnika među 123 fizioterapeuta na području Republike $\mathrm{Hr}$ vatske. Rezultati su pokazali da ispitanici doživljavaju svoje radno mjesto umjereno stresnim. Što se tiče razlike u doživljaju i percepciji stresa s obzirom na odjel na kojem fizioterapeuti rade, rezultati pokazuju da postoji statistički značajna razlika u razini percipiranog stresa među ispitanicima s obzirom na odjel na kojem su zaposleni. Utvrđeno je da ispitanici zaposleni na ortopediji u statistički značajno manjoj mjeri percipiraju stres u odnosu na ispitanike koji su zaposleni u domovima zdravlja te na odjelu fizikalne medicine i rehabilitacije. Razlika u percepciji stresa među ispitanicima zaposlenima na ostalim odjelima ne pokazuje statistički značajnu razliku. Utvrđeno je da ispitanici u dobi od 20 do 25 godina pokazuju statistički značajno manju razinu percipiranog stresa u odnosu na ispitanike u dobi od 26 do 36 godina. Između ostalih dobnih skupina ne postoji statistički značajna razlika u percepciji stresa. Utvrđeno je i da ispitanici s neto mjesečnom plaćom manjom od prosječne pokazuju statistički značajno veću razinu percipiranog stresa u odnosu na ispitanike s neto plaćom većom od prosječne. Rezultati istraživanja prikazuju da ne postoji statistički značajna razlika u razini percipiranog stresa među ispitanicima s obzirom na spol, godine radnog staža, stručnu spremu ili bračni status. 